\title{
The Quality of the Living Environment as a Result of Democratic Planning Traditions and Society Interaction: Aspect of Urban Public Security
}

\author{
Jonas Jakaitis, Vilnius Gediminas Technical University
}

\begin{abstract}
The article explores ways of improving urban structures of territories especially from the aspect of urban public security. The investigation is based on theoretical principles and existing practices. Implementing the principles of sustainable development in the conditions of public participation and cooperation with local authorities, residents of the cities and towns can be successfully integrated into a modern, well-designed, safe public urban space.
\end{abstract}

Keywords - Urban space security, local community, quality of life.

The article aims to discover and promote wider and deeper analysis of the problem of public safety as one of the most important quality of life indicators, stimulating expression of identity of territorial communities by optimisation of their formal territorial network. The problem is closely related to urban development policy which is implemented in many European countries, however, often there are political and democratic contradictions between the legal environment regulating standards and the level of quality of life felt by residents. The results of the monitoring carried out by the United Nations in 2013 [1] show, that in some major European cities, including also Vilnius (Fig. 1), one of critical factors affecting the quality of life is an issue of public safety. It is noted that $31 \%$ of the respondents rated public safety as one of the greatest threats to the quality of life conceding only to job creation and health services.

The guidelines of Lithuanian national policy [2] proclaim that control of the crimes committed in public places is recognized as a priority direction and one of the tasks in pursuit of the territory planning and urban operation is the creation of safe environment.

As the way of living is transforming, the concept of the criteria of quality of life is also changing. The interest of residents in the development of their native town, the informal interaction of dynamic (active citizen participation) and static (physical architectural environment) factors are particularly important conditions of life because they help in reflecting visual, emotional or functional meaning in the city form. Moreover, it allows res-

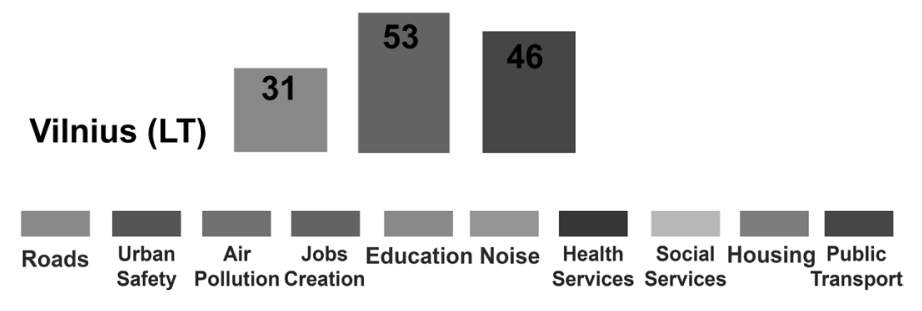

Fig. 1. Biggest threats to the quality of life level in Vilnius (2013). idents to see the values of the town and appreciate the participation of communities in architectural development of their own city, which therefore can help in transforming the city's image and creating unique architectural features characteristic of a particular age (Fig. 2).

Well thought out citizen participation in urban development based on democratic planning principles is the only legal way for citizens to express their opinion. However, citizen participation can be effective only if the community takes the responsibility for the consequences of actions performed or decisions made by people in the planning process [3].

Residential areas are differentiated according to the material environment conditions of communities and the relation of social society members to community-based organizations. Personal and public security is an essential goal of the state policy - security of constitutional human rights and freedoms conditions of implementation, which partly depend on the conditions in individual city. In Lithuania and partly in Vilnius there are different territorial levels of urban communities that could be identified in urban areas. Some trends of analysis are possible and the research will follow them. Starting from bigger and proceeding to a smaller, community of a complete territory could be identified in a state, region, city, district of a city and a sub district where the size of community in the case of Lithuania is about 3,000,000 people in the state, 550,000 in Vilnius including almost 80,000 of suburban residents, who associate their life with the city of Vilnius.

The next level down is stratus of urban residents in the big parts of the city, or so called city districts. These areas emerged historically during the informal long process of the development of the city of Vilnius. Such areas as the Old Town, the New Town, Užupis, Rasos, Šnipiškès, Žverynas and others can be listed in this case. These areas are still big by their territories. The territory of the Old Town is 450 ha, Rasos -1270 ha, Šnipiškès - 312 ha, the New Town - 480 ha, Žverynas -270 ha with the number of population in the Old Town $-21,000$, the New Town $-29,000$, Rasos $-13,000$, Šnipiškès $-20,000$, Žvèrynas $-12,200$. The territories of these city districts are mainly identified by similar environmental typology that formed in the city of Vilnius. The third level down of urban community is attributed to the territorial communities of districts (seniūnijos) - formal units of territorial community. The fourth level down is the informal level - local territorial communities of sub districts which are not created by the city government. These are informal territorial communities where every resident belongs to the neighbourhood of these areas and 


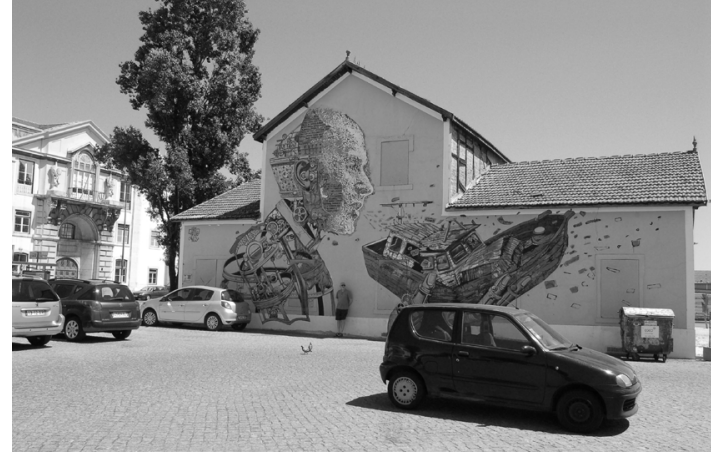

a).

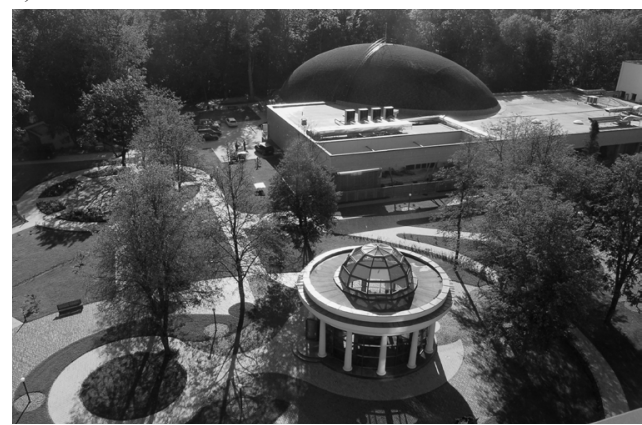

d).

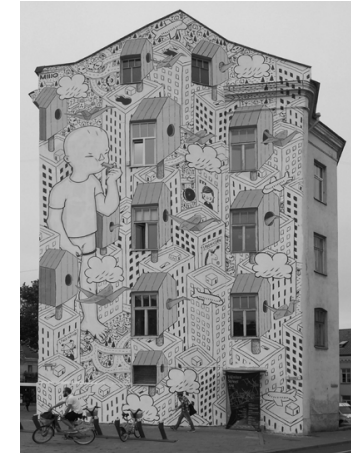

b).

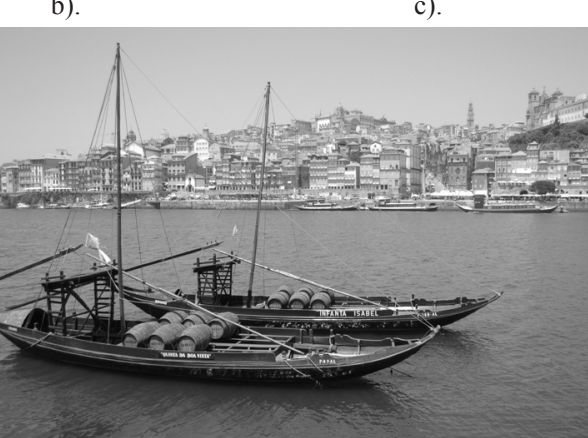

e).

c).
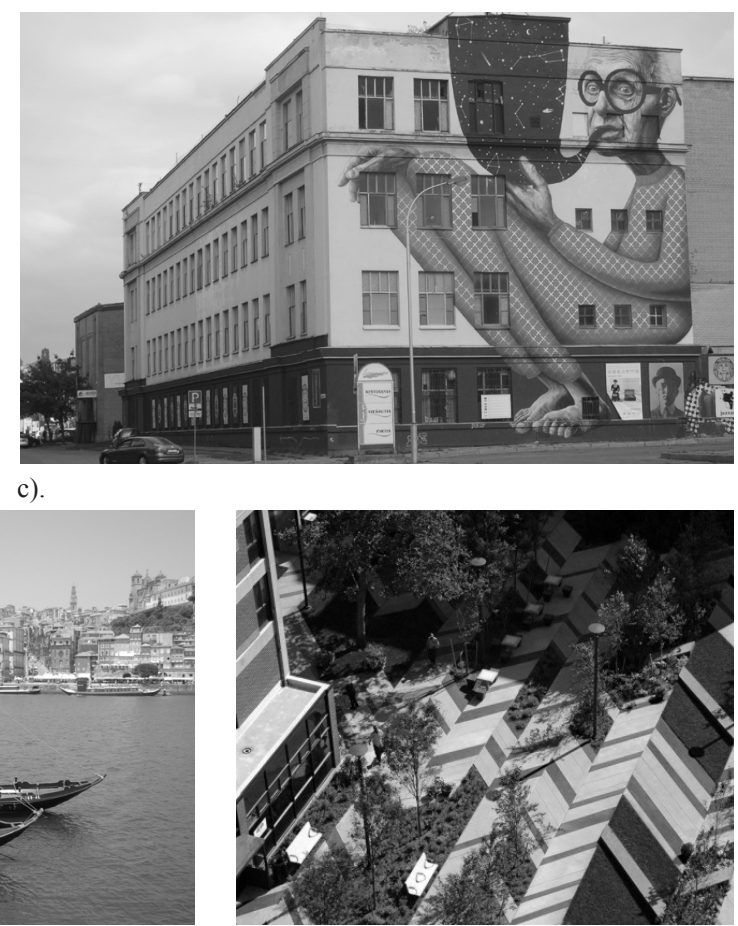

f).

2. Transformation of the city's image by the communities a) in Lisbon, b) in Vilnius, c) in Kaunas. d) Unique new urban structure (after renewal) in Druskininkai (Lithuania) as a compact, safe and poly-functional modern public space e) as unique old architecture in Porto (photo by J. Jakaitis); f) as harmonious public space in Israel (Chyutin Architects) (photo by J. Jakaitis).

the quality of life indicators have a strong impact on identifying the size and the boundaries of the territory that community is interested in. According to D. Held, "a community should be guided by a concept of the collectively created common good". [4] If, according to R. Buivydas (2006), citizens have no opportunities to actively participate and become aware of their role in the aforementioned planning process, most of them will always remain detached observers of democratic development and unable to participate in collective decision-making or discussions about the ways of creating common wealth [5], [3].

The goal of this article is to analyze different urban structures as objects influencing the quality of life through safe living environment interfaces and to introduce urban planning measures, permitting the reduction of threats to public safety.

\section{MethodologicAl BASES OF THE RESEARCH}

The problem of involving communities in sustainable development for better quality of life through safe living environment has been much discussed both on a national and international scale. The resolution adopted by the Lithuanian Government "On approving the list of fields of architecture to be developed in Lithuania" emphasizes that architecture has a significant role as it is a unique art in the country, implying that every citizen should actively participate in architectural development. According to Bristol Accord [6], the agreement adopted on 6-7 December 2005 at the informal meeting of ministers of foreign affairs from 12 EU countries, the key indicators of sustainable community were defined with the emphasis placed on the involvement of society in urban development of the border regions. Many arti- cles and monographs published by world researchers and various specialists on this problem, and plans and surveys also confirm the importance of the discussed problem [3]. According to the theory of Oscar Newman [7], criminality can be controlled and mitigated through great urban design. It is important to look at the city's development from a New Urbanist perspective, the new widely accepted planning paradigm in America that promotes higher density, mixed use communities based on the models of traditional European towns, communities in which one lives, works and plays all within a mile radius. The New Urbanism aims to create buildings, neighbourhoods and regions that provide better quality of life for residents while limiting negative environmental and social impacts. New ideas support the revitalization of existing urban structures and the reconfiguration of suburban sprawl to create healthy and sustainable towns and cities. The problem of informal participation and informal effect factors of society in developing urban architecture in Lithuania has been studied irregularly by various scientists such as J. Vanagas, A. Pociene, or art theorist R. Buivydas [8, 9, 10].

The author's research [11], [12] has determined that the impact of an object can be observed if it is $2 \mathrm{~km}$ away from an observer. When performing full-scale tests, the author confirmed these results and demonstrated that an object located within an informal community territory that is considered to be their own by the community members becomes important to them if that object is in the radius of $1-2 \mathrm{~km}$ from the centre of the area [3]. In addition, when the distance is $1-2 \mathrm{~km}$, it is possible to sense the social issues("informal" effect factor) and psychological state of communities. The data analysis indicates that the main principles of the urban development of the city not always have been taken 


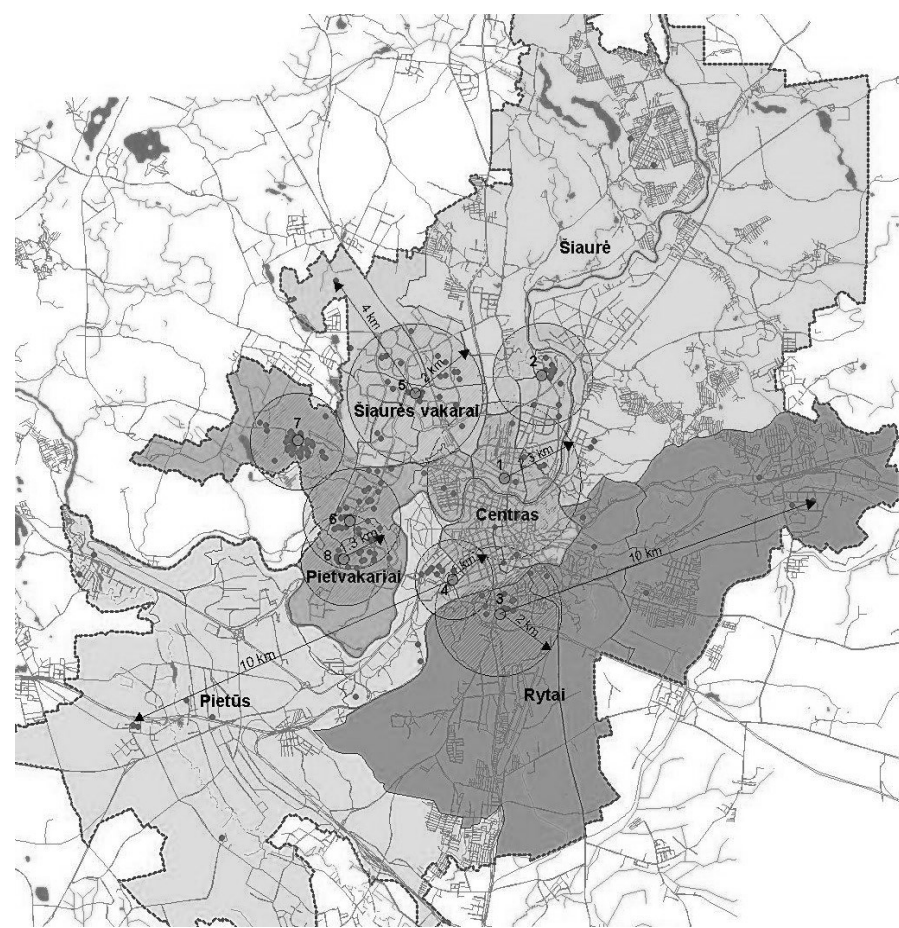

Fig 3. The network of informal territorial communities in Vilnius based on the data collected by the author in the city of Vilnius, city districts and sub districts (scheme was developed by J. Jakaitis).

into account. However, according those factors is suggested "informal" (Fig. 3) and "formal" territorial communities (Fig 4).

The author makes an assumption that the highest concentration level of public irregularities dominates in big attraction and shopping centres, public spaces and dense and heavy build-up residential areas (Fig. 5) [13].

However, the quality of life in the active areas of territorial communities, as well as the security of citizens is directly proportional to the compactness of urban structures, polycentricism and public activity. In order to examine these hypotheses, two experiments were conducted applying qualitative methods. The author succeeded to measure, compare and explain the factors assessed in foreign countries, with the factors affecting public safety in the case of the city of Vilnius (Table I).

\section{CAse Studies AND InVESTigations OF THE EXAMPLE OF VILNIUS}

According to Leon Krier, an English urban planner, "Simplicity must be the goal of the urban plan, however complex the urban geography and topography. The city must be articulated into public and domestic spaces, monuments and urban fabric, classical architecture and vernacular buildings, squares and streets, and in that hierarchy." So, the investigation aims to provide a common language around the definition of best practice sustainable communities [17], encourage innovation and excellence in the approach to creating future communities, promote integration across the field of sustainability issues related to goods of communities and provide a basis for ongoing evaluation of sustainable, safe community evolution.

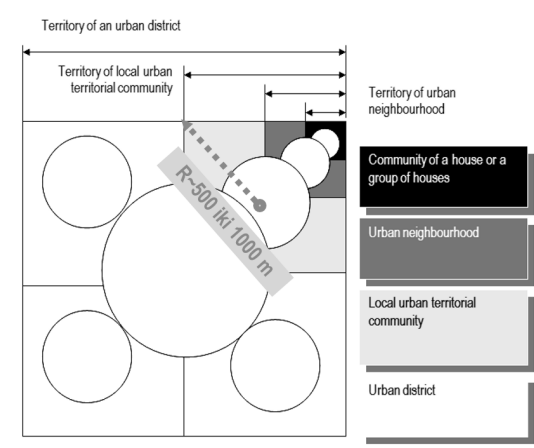

a).

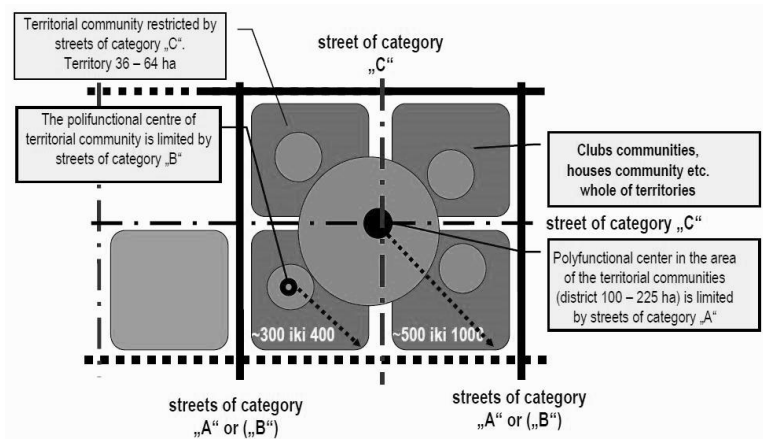

b).

Fig 4. The formal models a) hypothetica, b) realistic, of local territorial communities (schemes by J. Jakaitis).

Case study Nr. 1. While conducting the study, the author identified territories, where the greatest impact on public security was made by the buildings shaping the urban environment build up indicators - height, density and area of a territory. The calculations were carried out by grouping the spread of public order violations according to the dislocation of different types of buildings in informal areas of Vilnius (Fig. 6) and after statistical analysis the authors [13] are presenting the results of the investigation.

The study derivative indicators are as follows [12], [13]:

- correlation coefficient of the number of crimes and build up intensity ('r'(Cr\&I.));

- correlation coefficient of the number of crimes and the heights ('r' (Cr.\&H)).

The values of these indicators are presented in Table 1. The results show that in the central part of the city safety mainly is not influenced by the height of buildings but by attraction centres and public spaces that have no coherence with urban structure, that form around anonymous, easily transitive and transit territories.

The author found that the biggest threat to public security in the residential quarters according to environmental monitoring facilities is in the group of houses that are higher than 5 storeys. These areas are characterized as misbalance of urban structure, architecture and community needs. This determines tenuous communal relations and decrement of responsibility for the living environment. These results are similar to analogous study results [14], [15], [9] that were carried out in America, Great Britain and Australia. 


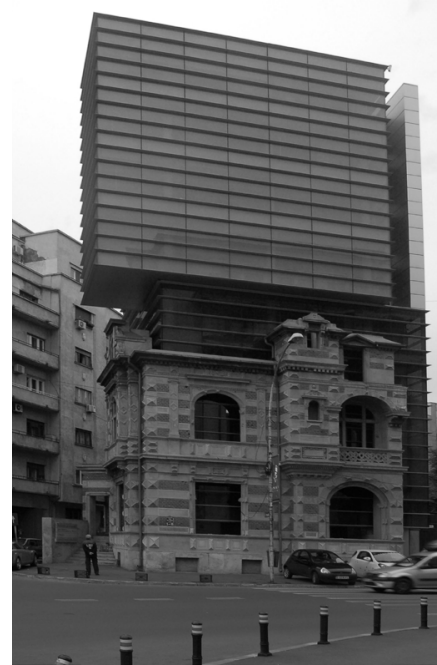

a).

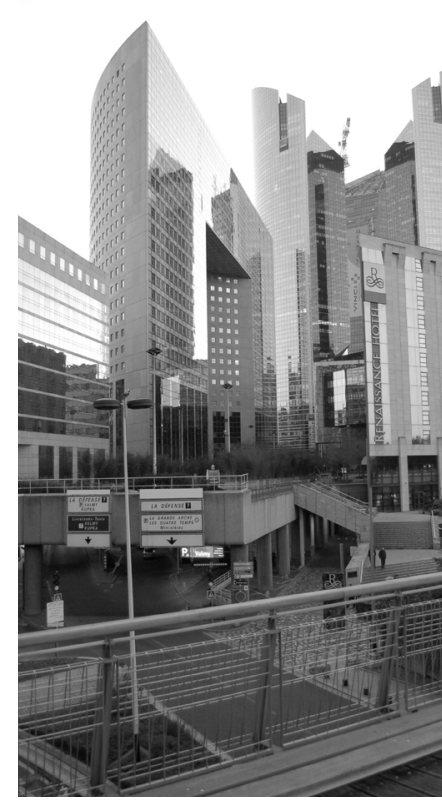

b).

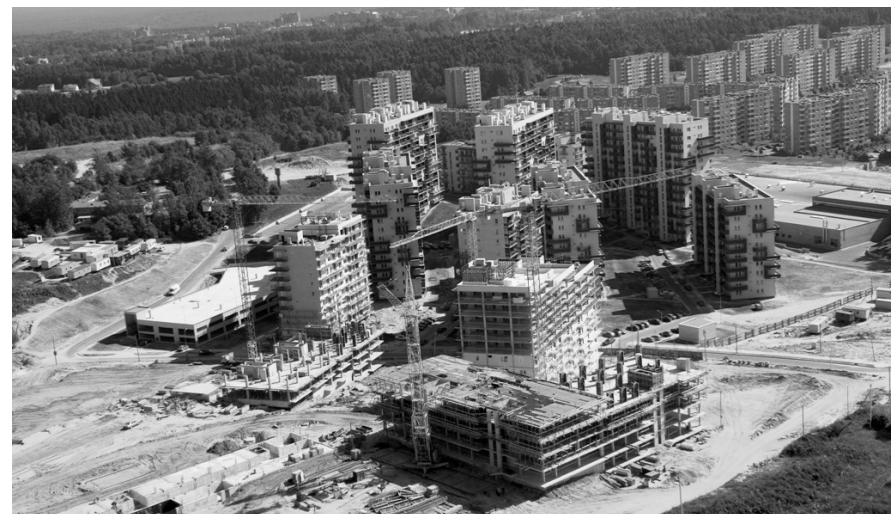

c).

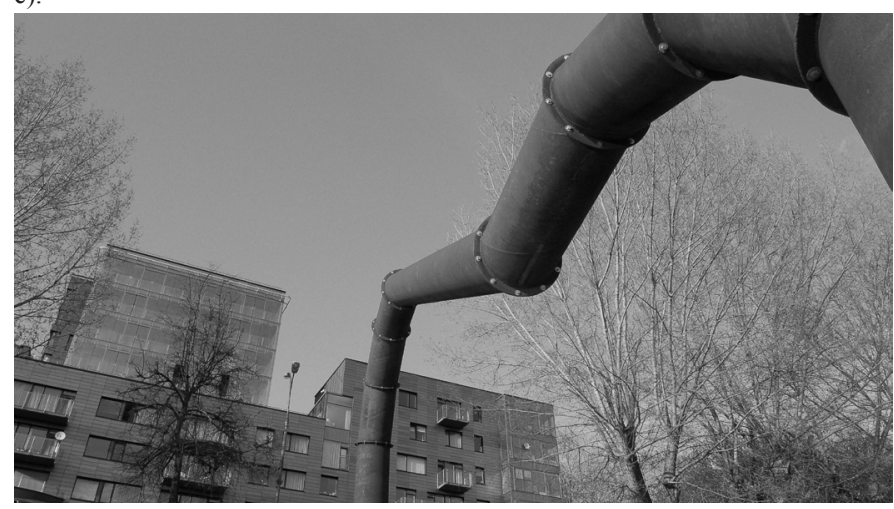

d).

Fig. 5. Unsafe and unbalanced urban environment is created by, for example a) low-quality architecture in Bucharest, b) hyper high density in Paris, c) and d) low-quality of urban architecture and of the material environment design in Vilnius (photos by J. Jakaitis).

TABLE I

DEPENDENCY OF Number of CRIMES ON BUILD up PARAMETERS IN DifFerent Types OF URBAN AREAS

\begin{tabular}{|l|l|l|l|}
\hline & 'r' $(\mathrm{Cr} \& \mathrm{I})$. & ${ }^{\prime} \mathrm{r}$ ' (Cr.\&H) & disparity \\
\hline Central part of city & 0.554 & 0.274 & 0.280 \\
\hline Areas of blocks of flats & 0.570 & 0.545 & 0.025 \\
\hline Areas of low-rise buildings & 0.363 & 0.288 & 0.075 \\
\hline Peripheral low-urbanized areas & 0.303 & 0.131 & 0.172 \\
\hline
\end{tabular}

TABLE II

The Derivative Study DATA on the Impact of Informal Communities on Public SeCURITY

\begin{tabular}{|c|c|c|c|c|c|c|c|}
\hline & \multirow{2}{*}{$\begin{array}{l}\text { Index of Polycen- } \\
\text { tric (Ipoly) }\end{array}$} & \multicolumn{2}{|c|}{ Road density (m/ha) } & \multicolumn{4}{|c|}{ Delinquency per 1000 inhabitants } \\
\hline & & $\begin{array}{l}\text { Rapid-speed } \\
\text { streets }\end{array}$ & Total street & Conflicts & Fighting & Murder & Total \\
\hline IZ 1 & 0.11 & 16.7 & 108.0 & 0.69 & 0.05 & 0.00 & 0.75 \\
\hline IZ 2 & 0.22 & 10.4 & 71.5 & 0.84 & 0.16 & 0.10 & 1.03 \\
\hline IZ 3 & 0.18 & 17.1 & 86.5 & 0.67 & 0.10 & 0.03 & 0.80 \\
\hline IZ 4 & 0.34 & 24.6 & 78.4 & 0.70 & 0.12 & 0.02 & 3.66 \\
\hline IZ 5 & 0.20 & 4.9 & 81.2 & 0.61 & 0.09 & 0.02 & 3.43 \\
\hline
\end{tabular}

Case study No.2. In addition to the results of the first experiment, the 2nd experiment assesses the relation between the inhabitants and the living environment, where residents are most active. The activity index of the community participants is directly depending on the awareness of the population and index of polycentricism (Ipoly) [12].

During the study, in each zone of informal territory (Fig. 6) the authors [13] identified the most important centres of attraction, around which, in view of the urban environment, were determined the ranges of availability. In this range the authors evaluated the values of urban structure indicators and delinquency dispersion, and compared these values with each other (Table II).

By applying the method of statistical analysis the interplay correlation of the introduced data is presented (Table III).

The authors found, that the density of road network and polycentricism has the greatest impact on public safety, and the increasing 


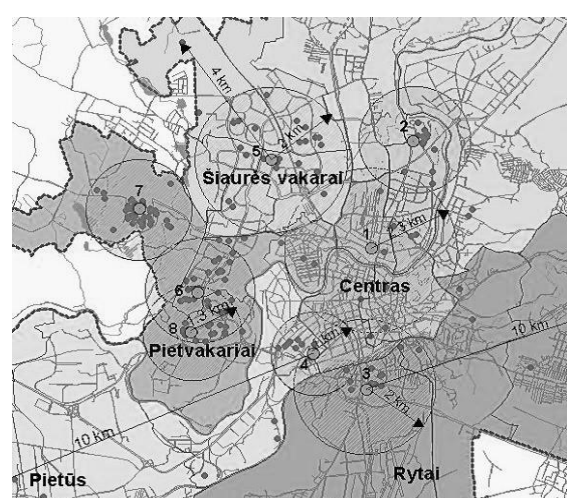

a).

Fig. 6 The analysis of a) informal territorial community network in Vilnius based on the data by the author and b) areas af

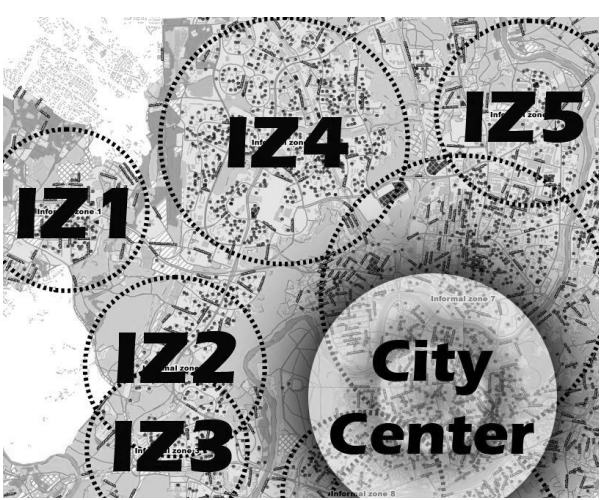

b).

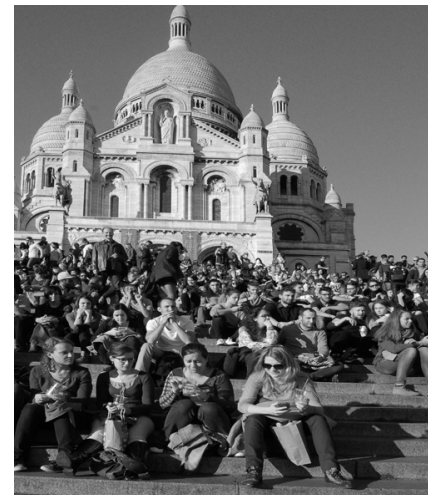

a).

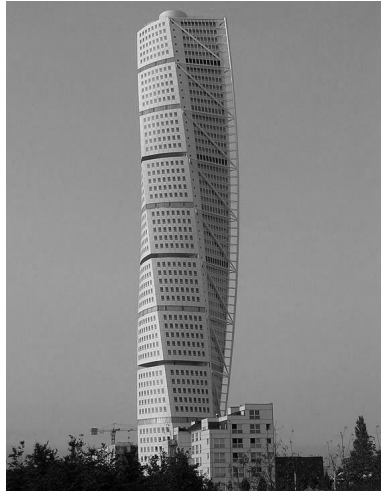

b).

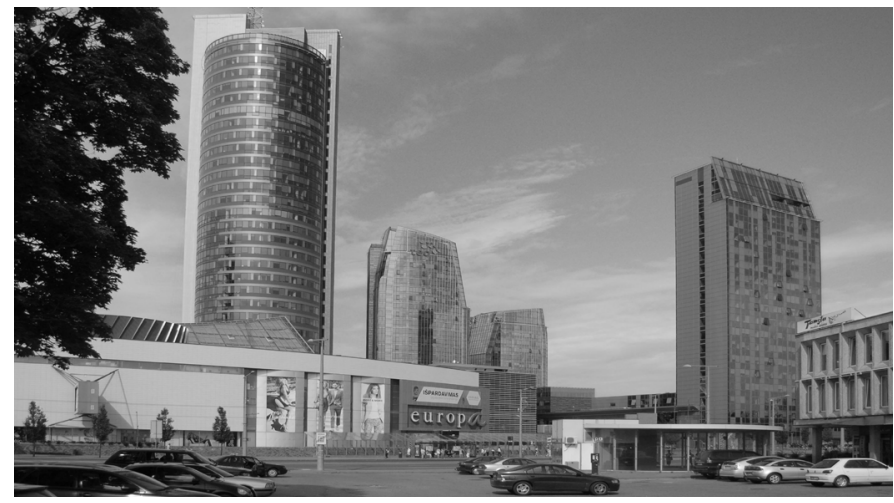

c).

Fig. 7. a) Historical centre of Paris (unique static factor); b) new compact modern building in poly-functional living district in Malmö with a new - formed building (unique static factor) - Turning Torso skyscraper which has become the symbol of modern architecture and community identity sign not only for Malmö but also for the whole Sweden; c) modern centre of city of Vilnius (photos by J. Jakaitis).

TABLE III

Statistical ANALysis of DATA

\begin{tabular}{|l|l|}
\hline Ipoly and total crime per 1000 inhabitants & 0.71 (strong) \\
\hline Rapid-speed roads density and total crime per 1000 inhabitants & 0.03 (no impact) \\
\hline Total road density and total crime per 1000 inhabitants & 0.41 (weak impact) \\
\hline
\end{tabular}

territorial uncertainty determines the trend of alienation growth. Lithuania had survived such period during the Soviet times, when people were convinced that everything is common and there was no necessity to have one's own space [12]. These circumstances informally, together with political factors, shape the features of urban identity: structure, style, functional connections or social urban content and security in the system of territorial communities.

\section{CONCLUSIONS AND RECOMMENDATIONS}

After the evaluation of the study results, statistical information and practice in other countries in implementing measures of public safety in the cities, urban planning measures at the national level would significantly improve public safety which is one of the most important criteria of the quality of life.

In the city of Vilnius urban structure can be used as a preventive measure of landscaping and urban planning of public safety; it is possible to apply the model of "informal territorial communities" (Fig. 3) - defining the area, which is home to an organized, active and public-minded community. Such territories have clear boundaries and controlled access to the internal space. Analogous, decentralized urban environment formation model is widely applied in many cities in Germany, Scandinavian countries and other cities of the democratic world [16]. By implementing the principles of sustainable development under the conditions of community participation and cooperation with local authorities, residents of the cities and towns of Lithuania can be successfully integrated into a modern, well-designed and compact, safe public urban space. Comfortable and healthy environment is a result of joint efforts, proper choice and good projects (Fig. 7) [3].

Their uniqueness comes from a mixed build up applying a multifunctional polycentric urban structure at the same time regulating the build up height, providing sufficient community infrastructure objects and access to public goods and security. 


\section{REFERENCES}

1. United Nation Human Settlements Programme : State of the World's Cities 2012-2013 : Prosperity of Cities. London, Sterling, VA: UN-HABITAT, 2013. 224 p. ISBN13:978-0-415-83888-7.

2. Parliament of the Republic of Lithuania. LR Parliament decree about approval of national prevention and inspection program of criminal activities. Vilnius, 2003.

3. Jakaitis, J. Interaction of architecture and society : city individuality under changeable informal effect conditions : Urban growth without spraw : A way towards sustainable urbanization : 44th ISOCARP congress. Congress papers, introductory reports, short outlines of paper [CD]. Dalian: ISOCARP, 2008. p. 1-7. ISBN 9787806846841.

4. Held, D. Models of Democracy. Cambridge: Polity and Stanford University Press, 1987.321 p.

5. Buivydas, R. Architecture : Negatives and positives of architecture. Vilnius: Ex Atre, 2006. 224 p.

6. Conclusions of Bristol Ministerial Informal Meeting on Sustainable Communities in Europe : UK Presidency. Office of the Deputy Prime Minister. Bristol, 2005. 19 p.

7. Newman, O. Defensible Space : Crime Prevention Through Urban Design. New York: Macmillan, 1972. 264 p.

8. Vanagas, J. From the Cave Shelter to the Modern Megalopolis. Vilnius: Technika, 2012. 194 p.

9. Pociene, A. Social order and security assumptions in the city : Western experience in applying environmental criminology theories and outlook in Lithuania. Low Institute, 2009.

10. Buivydas, R. Viešųų erdvių transformacija Lietuvos miestuose. LOGOS 66, sausis. 2011.

11. Jakaitis, J. Aspects of interaction of the city architecture and society : By the example of Vilnius City / Univer-City : the old middle-sized European academic town as framework of the global society of science-chalenges and posibilities. Grahns Tryckeri AB. Lund, 2008. p. 428-440. ISBN 9789185767182

12. Jakaitis $\mathbf{J}$. A discourse on the members of urban spatial formation under conditions of modern democracy : Monograph. Vilnius: Technika, 2013. 220 p. ISBN 978-609-457-475-7.

13. Jakaitis, J.; Bielinskas, V. Public Safety as a Democratic Town Planning Measures Results (in the context of Vilnius city). КазНТУ. Алматы, 2013 p. 193-196. ISBN 978-601-228-551-2 (Материалы Международной научно-практической конференции «Актуальные проблемы большого города: архитектурная теория и практика»).

14. Vileikienė, E. Lithuanian population approach to public safety assessment. Vilnius, 2012. 48 p. [online, cited 01.09.2014]. www.policija.lt/get. php?f.11102

15. Jacobs, J. The Death and Life of Great American Cities. New York: Random House, 1961. 480 p. ISBN 0-679-60047-7.

16. Jakaitis, J., Paliulis, N. K., Jakaitis, K. Aspects of the national urban policy management under conditions of integrated planning. Technological and economic development of economy : Baltic journal on sustainbility Vilnius: Technika. Vol. 15, no 1, 2009. p. 26-38.

17. Hansen, S. Looking to the Village for Tomorrow's City Design [online]. Sourceable : Industry News and Analysis [cited 10.09.2014]. http://sourceable.net/looking-village-tomorrows-city-design/

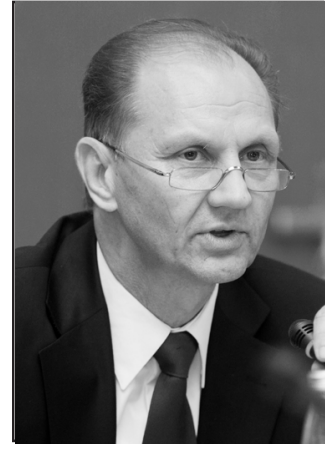

Jonas Jakaitis holds $\mathrm{PhD}$ in Arts and is an Assoc. Professor and Head of the Department of Design of Vilnius Gediminas Technical University. He is Head of the Institute of Architecture. He is a member of Architects' Association of Lithuania and Lithuanian Association of Landscape Architects. $\mathrm{He}$ is involved in a number of programmes, projects and commissions. He is a certified architect expert, an expert of the Lithuanian Evaluation Centre of the Quality of Studies and a member of the Certification Commission of Architects under the Ministry of Environment of the Republic of Lithuania. He has participated in many international and national conferences and seminars and is the author of more than 40 publications, a number of teaching materials and monograph A Discourse on the Members of Urban Spatial Formation under Conditions of Modern Democracy (2013). He has participated in the development of more than 35 projects on science and architecture on individual basis or in cooperation with others, assisted in developing the Master Plan of the City of Vilnius (2006) and many details and special planning documents. He is a prize-winner of several contests.

J. Jakaitis is a member of Editorial Boards of scientific periodicals Acta Architecturae Naturalis (Tallinn University of Technology) and Civil Engineering and Architecture (Horizon Research Publishing, HRPUB, USA, ).

His research interests are urban planning and design, landscape architecture and the design of material environment, planning regulations and democracy, public and private partnership and public participation in urban architecture and sustainable formation of living environment from details to a large picture.

J. Jakaitis has received awards from the Prime Minister of the Government of the Republic of Lithuania, the Parliament's Committee on Environment Protection and the Majors of Vilnius.

\section{CONTACT DATA}

Jonas Jakaitis

Vilnius Gediminas Technical University, Saulètekio ave. 11, LT-10223 Vilnius, Lithuania;

Pylimo str. 26/1, LT-03227 Vilnius, Lithuania.

E-mail: jonas.jakaitis@vgtu.lt archinst@vgtu.lt 